\title{
Design Of Brake Water Destilation Tools Using Sun Energy For Providing Clean Water For Communities In Coast Coast Of Napae
}

\author{
Dedy Nataniel Ully ${ }^{1}$, Vinsensius Faot ${ }^{1}$, Agus Laka ${ }^{1}$ \\ \{dedy.ully@gmail.com, vinsen.faot@gmail.com, agus.laka@gmail.com\} \\ Politeknik Negeri Kupang ${ }^{1}$
}

\begin{abstract}
People who live in coastal areas are often faced with the problem of the availability of clean water to meet their daily needs. This happens because water sources around the coastline generally have brackish or salty taste, one of which is the Napae coastline. The purpose of this study is to determine the efficiency of using box and triangle type absorbent plates made of stainless steel. Tests carried out at 9:00 to 16:00 with the volume of water in the distillator as much as 50 liters. The results showed that the efficiency increased parabolically over time, so it has a tendency to decrease at 14:00 to 16:00 WITA. The highest efficiency occurs at 13.00 WITA ie with a box type absorber of $14.51 \%$ while in the triangle type absorbent the highest efficiency occurs at 12.00 WITA of $12.80 \%$, this happens because at this time the sun emits its solar radiation to the maximum.
\end{abstract}

Keywords. brackish water, distillation, absorbent and solar energy.

\section{Introduction}

Availability of water resources that are not limited in quantity, indeed only sea water or brackish water. However, the quality is very bad because it contains high levels of salt or TDS (Total Dissolved Solid). If you consume brackish water for a long time, it can cause various diseases, such as abdominal pain, especially diarrhea and cholera and high blood pressure (hypertension) which can lead to death. In addition, using brackish water for consumption as well as for other activities such as bathing, can interfere with health. Because brackish water contains high $\mathrm{NaCl}$ (Sodium Chloride) and can interfere with metabolism that occurs in the human body. When used for bathing, it can trigger various skin diseases, such as itching, scabies, tinea versicolor and eczema. For long-term use, it is not impossible that people who consume brackish water will experience serious disease because their metabolism is disturbed, because the body is sensitive to brackish water containing salt [1].

To overcome this problem, efforts are needed to manage water resources using brackish water treatment technology into fresh water, which is in accordance with the social conditions of the community and natural resources in an area such as on the Napae coast. Brackish water treatment is through a process of distillation or distillation in advance by using solar radiation absorption plates on flat and corrugated media types made from stainless steel, so as to get clean 
water that is suitable for consumption and does not have a negative impact on public health. The purpose of this distillation process is to separate the excessive salt element contained in water, by heating it with solar energy and then evaporating and condensing or condensed, so that the hot steam changes phase into clean, non-salty water. For this reason, it is necessary to find a way out by making a brackish water distillation plan for people in the coastal area, especially for people in Napae.

However, research on brackish water distillation into fresh water has been carried out by previous researchers in an effort to improve the performance of the design of tools made. Efforts to improve the performance design of distillation equipment that has been done previously is by conducting research on the design and performance test of the distalination system using solar heat with air pressure regulation. The purpose of this research is to design and make seawater desalination equipment that can be used for water purification or purification by utilizing solar energy and to test the performance of the designed device. The method used in this study is the design of tools that include functional analysis and structural analysis and proceed with testing the performance of the tool that has been designed.

Based on the results of the design and testing of distillation systems using solar heat with air regulation the following conclusions are obtained; Seawater desalination tool works based on the colligative nature of the solution regarding the boiling point ie a liquid is said to boil if the vapor pressure is equal to atmospheric pressure above the liquid surface. The higher the atmospheric pressure the higher the boiling point of the liquid and vice versa the lower the atmospheric pressure the lower the boiling point of the liquid [2].

Next, research on chemical-based brackish water treatment through reverse osmosis (RO) membrane technology combined with coagulant and ion exchange.

The purpose of this study is to reduce the parameters of water parameters in brackish water based chemical treatment using RO membrane technology combined with coagulant aid and ion exchangers.

Conclusions of the study: Chemical-based brackish water treatment through reverse osmosis (RO) membrane technology combined with coagulants and ion exchangers obtained removal parameters: Total Disolved Solid (TDS) $1422 \mathrm{mg} / \mathrm{L}$, Turbidity 1.99 NTU Scale, Color 15 Unit Pt Co, Power Electric Conduct (DHL) 2430 mhos / cm, Iron 0.13 mg / L Fe, Fluoride $0.3 \mathrm{mg} / \mathrm{LF}$, Total Hardness

$228.57 \mathrm{mg} / \mathrm{L}$ CaCO3, Chloride $796 \mathrm{mg} / \mathrm{L} \mathrm{Cl}$, Sodium $526.7 \mathrm{mg} / \mathrm{L} \mathrm{Na}$, Nitrate $2.46 \mathrm{mg} / \mathrm{L}$ NO3-N, Zinc $0.09 \mathrm{mg} / \mathrm{L}$ Zn, Sulfate $73.18 \mathrm{mg} / \mathrm{L}$ SO4, Detergent $0.09 \mathrm{mg} / \mathrm{L}$ LAS, and Total Coliform of $10890 \mathrm{MPN} / 100 \mathrm{~mL}$ [3].

Subsequent research is about analyzing the thermal performance of solar apparatus panels on brackish water distillation devices with a solar steam evaporation system using CFD. To find out the thermal performance of this distillation tool, a research was conducted with a simulation method using a computational fluid dynamic (CFD) approach using GAMBIT 2.4.6 software in the domain creation phase which was then simulated using ANSYS FLUENT 13 software. Simulations were carried out on a three dimensional solar apparatus panel (3D) using the Realizable k- $\varepsilon$ turbulence model, solar load model and Rosseland radiation model. Furthermore, the simulation is done with variations the speed of water flow into the pipe is $0.01 \mathrm{~m} / \mathrm{s}, 0.02 \mathrm{~m}$ $/ \mathrm{s}, 0.03 \mathrm{~m} / \mathrm{s}$ and $0.04 \mathrm{~m} / \mathrm{s}$. From the results of modeling and analysis, it is known that the largest temperature distribution is in the pipe. The maximum energy that can be received by water is $369,591 \mathrm{~W} / \mathrm{m} 2$ at 10:00 at a speed of $0.04 \mathrm{~m} / \mathrm{s}$. The value of heat losses that occur at each speed is inversely proportional to the value of efficiency which decreases every hour, the average efficiency occurs in the afternoon starting at 11:00 - 13:00. The average efficiency value at the speed of $0.01 \mathrm{~m} / \mathrm{s}$ is $27.6 \%$. At a speed of 0.02 which is $30.2 \%$. On speed 
0.03 is $31.6 \%$ while at a speed of 0.04 is $33.4 \%$ [4].

Furthermore, research was carried out on distillation of sea water using solar heaters with concave mirror reflectors. Reflectors are placed on the ground and directly illuminated by the sun. Collectors containing seawater samples are placed above the reflector at the position of the focal point. During heating by sunlight, the temperature is measured every hour with the observation time starting at 08.00 to 16.00 WIB. Observations were made for seven days and selected fine weather.

The results showed that the maximum temperature of sea water samples using a reflector of $100^{\circ} \mathrm{C}$ and the maximum temperature at the focal point was $140^{\circ} \mathrm{C}$ and the highest daily distillation yield was $688 \mathrm{ml}$. The observation results for distillation without reflector obtained a maximum temperature of sea water samples at $64^{\circ} \mathrm{C}$ and the highest daily volume produced at $180 \mathrm{ml}$. The results of laboratory testing of water samples before and after distillation showed a very significant improvement in quality, especially salinity decreased to 0 after distillation from $27.5 \mathrm{ppt}$ before distillation [5].

Furthermore, research was conducted on sea water treatment using a steam generator to produce fresh water. Siak Kecil and Bukit Batu subdistricts in Bengkalis district get clean water that feels salty. In this study, sea water will be processed into freshwater that is suitable for drinking through a steam generator. This process utilizes thermal energy to vaporize salt water. The water vapor is then cooled into water points and the results are stored as fresh, clean water. Clean water produced from the distillation process has a very good level of health when compared to clean water that comes from processing using chemicals. The quality of water produced is $22 \mathrm{ppm}$ (parts per million) using a TDS meter [6].

\section{Experimental and Procedure}

This research was conducted using true experimental methods (true experimental) that is conducting direct observations in the field where the research location in the coastal area of Napae to find cause and effect data in a process through experiments so that it can determine the effect of absorption of solar radiation on corrugated and plate type media flat made from stainless steel in the design of brackish water destlator on the coast of Napae, where the same treatment is carried out on both types of absorbent that is the time of data collection simultaneously to determine maximum performance.

The aim of this field-scale research is to find out the effect of the use of a box type and triangle-based solar radiation absorber, so that the efficiency of these two types of absorbent plates can be known. In addition, under the two absorbent plates filled with gravel with the rationale that gravel can store heat so that it can accelerate the evaporation process inside the destilator itself. Installation research in the form of a distillator with a box type and triangle type solar radiation absorber can be seen in Figures 1 and 2 as shown in the figure below: 


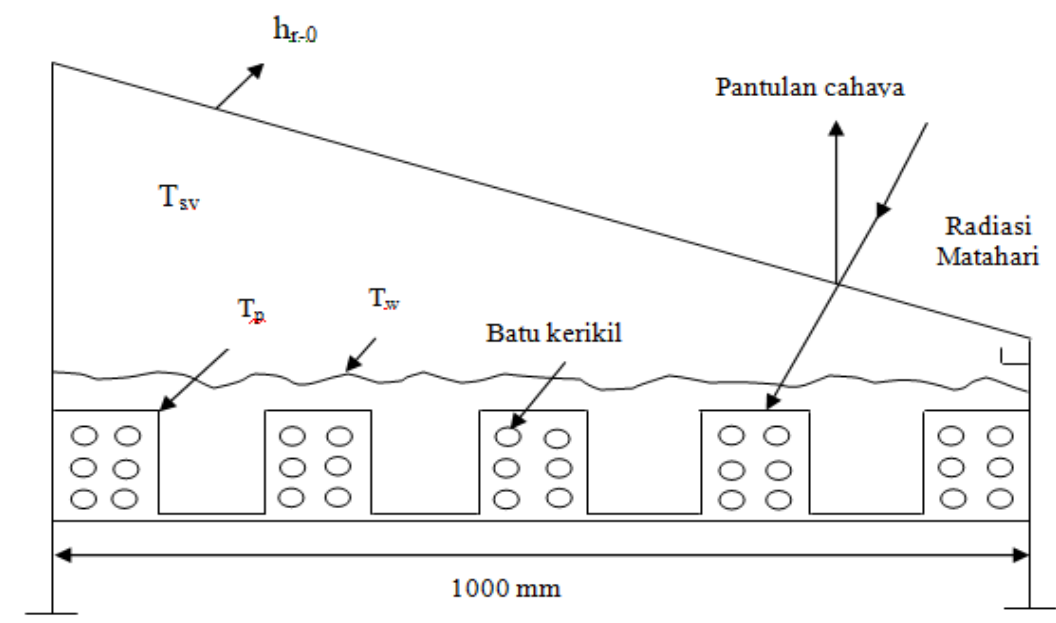

Figure 1. Research installation with a box type absorber.

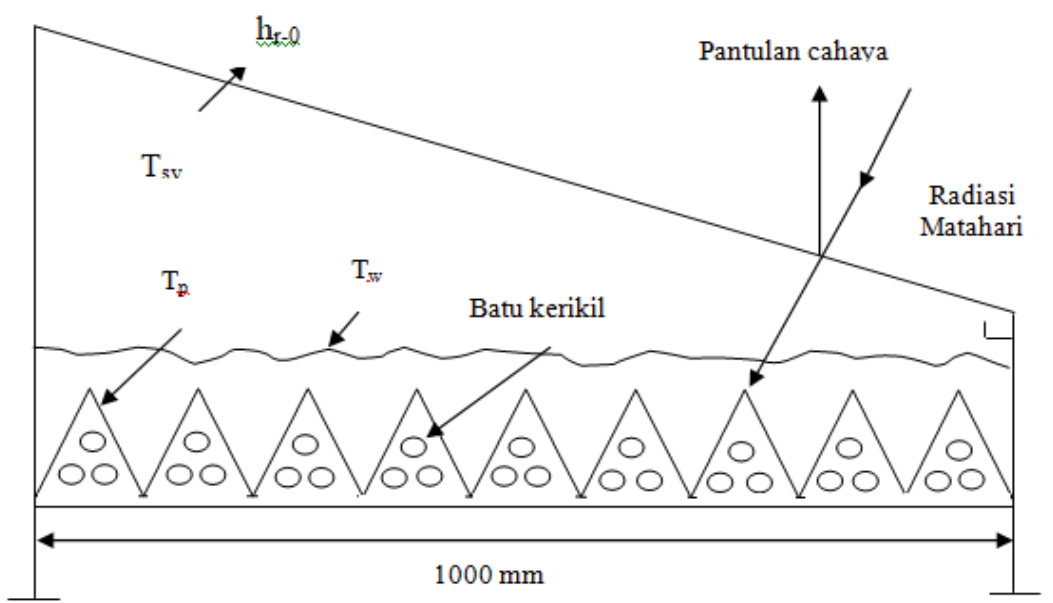

Figure 2. Installation of research with a triangle type absorber.

Caption :

IT = solar intensity $(\mathrm{W} / \mathrm{m} 2)$.

qr, $1=$ The rate of radiation heat transfer from the collector to the surface in the glass (Watt).

qc, 1 = Convection heat transfer rate from water vapor to the surface in the glass (Watt).

$\mathrm{qc}, \mathrm{w}=$ The rate of convection heat transfer from water to water vapor (Watt).

$\mathrm{Qk}=$ Conduction heat transfer rate from the collector to the outer wall (Watt).

$\mathrm{qr}, \mathrm{O}=$ The rate of radiation heat transfer from the glass to the environment (Watts).

$\mathrm{qc}, \mathrm{O}=$ Convection heat transfer rate from the glass surface to the environment (Watt).

$\mathrm{Ta}=$ Environmental temperature $(\mathrm{O} \mathrm{C})$.

$\mathrm{Tw}=$ water temperature $(\mathrm{O} \mathrm{C})$.

$\mathrm{Tc}=$ glass surface temperature $(\mathrm{O} \mathrm{C})$. 
$\mathrm{Tsv}=$ Water vapor temperature $(\mathrm{O} C)$.

$\mathrm{Tp}=$ Temperature of absorbent plate (O C).

\subsection{Equations, formulas and code}

\section{Useful Energy Collektor}

$$
\begin{aligned}
& Q_{U}=Q_{I n}-Q_{\text {Out }} \\
& Q_{U}=\left(\alpha . I T \cdot A_{c} \cdot \tau\right) \cdot\left(U _ { L } \cdot A _ { c } \left[\left(U_{L} \cdot A_{c} \cdot\left(T_{P}-T_{A}\right)\right]\right.\right.
\end{aligned}
$$

\section{Useful Energy Distillation}

$$
Q_{u-d}=\frac{m k \cdot h_{f g}}{t}
$$

\section{Efficiency Of The Destillation}

$$
\eta_{d}=\frac{m k \times h_{f g}}{A_{c} \times I_{T} \times t} \times 100 \%
$$

\section{Results And Discussion}

\subsection{Result}

Table 1. Data from the test and processing of box type solar radiation absorber

\begin{tabular}{cccccccccc}
\hline Time & $\begin{array}{c}\mathrm{T}_{\mathrm{a}} \\
\left({ }^{\mathrm{O}} \mathrm{C}\right)\end{array}$ & $\begin{array}{c}\mathrm{T}_{\mathrm{c}} \\
\left({ }^{\mathrm{O}} \mathrm{C}\right)\end{array}$ & $\begin{array}{c}\mathrm{T}_{\mathrm{w}} \\
\left({ }^{\mathrm{O}} \mathrm{C}\right)\end{array}$ & $\begin{array}{c}\mathrm{T}_{\mathrm{p}} \\
\left({ }^{\mathrm{O}} \mathrm{C}\right)\end{array}$ & $\begin{array}{c}\mathrm{T}_{\mathrm{sv}} \\
\left({ }^{\mathrm{O}} \mathrm{C}\right)\end{array}$ & $\begin{array}{c}\mathrm{m}_{\mathrm{k}} \\
(\mathrm{kg})\end{array}$ & $\begin{array}{c}\mathrm{I}_{\mathrm{T}} \\
\left(\mathrm{W} / \mathrm{m}^{2}\right)\end{array}$ & $\begin{array}{c}\mathrm{Qu}_{\mathrm{d}} \\
(\mathrm{kW})\end{array}$ & $\begin{array}{c}\eta_{d} \\
(\%)\end{array}$ \\
\hline 0.900 & 34.83 & 35.60 & 39.56 & 42.90 & 33.43 & 0.09 & 585.81 & 0.0645 & 8.57 \\
0.100 & 36.53 & 37.70 & 43.86 & 45.14 & 36.56 & 0.14 & 765.50 & 0.0939 & 10.22 \\
11.00 & 39.63 & 41.30 & 48.56 & 52.63 & 39.26 & 0.18 & 837.62 & 0.1204 & 11.98 \\
12.00 & 41.26 & 42.56 & 58.56 & 54.53 & 40.63 & 0.22 & 873.20 & 0.1469 & 14.02 \\
13.00 & 42.73 & 43.70 & 58.76 & 61.23 & 40.36 & 0.23 & 882.42 & 0.1537 & 14.51 \\
14.00 & 38.36 & 42.13 & 52.66 & 58.86 & 38.56 & 0.21 & 858.00 & 0.1405 & 13.65 \\
15.00 & 38.70 & 39.53 & 52.85 & 55.66 & 38.90 & 0.18 & 783.24 & 0.1204 & 12.81 \\
16.00 & 35.70 & 37.36 & 51.73 & 54.56 & 36.66 & 0.12 & 583.08 & 0.0804 & 11.5 \\
\hline
\end{tabular}


Table 2. Data from testing dan processing of triangle type solar radiation absorbent

\begin{tabular}{cccccccccc}
\hline Time & $\begin{array}{c}\mathrm{T}_{\mathrm{a}} \\
\left({ }^{\mathrm{O}} \mathrm{C}\right)\end{array}$ & $\begin{array}{c}\mathrm{T}_{\mathrm{c}} \\
\left({ }^{\mathrm{O}} \mathrm{C}\right)\end{array}$ & $\begin{array}{c}\mathrm{T}_{\mathrm{w}} \\
\left({ }^{\mathrm{O}} \mathrm{C}\right)\end{array}$ & $\begin{array}{c}\mathrm{T}_{\mathrm{p}} \\
\left({ }^{\mathrm{O}} \mathrm{C}\right)\end{array}$ & $\begin{array}{c}\mathrm{T}_{\mathrm{sv}} \\
\left({ }^{\mathrm{O}} \mathrm{C}\right)\end{array}$ & $\begin{array}{c}\mathrm{m}_{\mathrm{k}} \\
(\mathrm{kg})\end{array}$ & $\begin{array}{c}\mathrm{I}_{\mathrm{T}} \\
\left(\mathrm{W} / \mathrm{m}^{2}\right)\end{array}$ & $\begin{array}{c}\mathrm{Q}_{\mathrm{U}-\mathrm{d}} \\
(\mathrm{kW})\end{array}$ & $\begin{array}{c}\eta_{d} \\
(\%)\end{array}$ \\
\hline 0.900 & 34.83 & 35.13 & 32.93 & 34.06 & 31.53 & 0.07 & 585.81 & 0.0471 & 6.71 \\
0.100 & 36.53 & 37.26 & 39.46 & 40.43 & 34.33 & 0.12 & 765.50 & 0.0806 & 8.78 \\
11.00 & 39.63 & 40.73 & 39.43 & 40.66 & 35.70 & 0.16 & 837.62 & 0.1074 & 10.68 \\
12.00 & 41.26 & 42.20 & 54.90 & 56.43 & 36.56 & 0.20 & 873.20 & 0.1341 & 12.80 \\
13.00 & 42.73 & 43.43 & 55.16 & 56.26 & 36.46 & 0.19 & 882.42 & 0.1274 & 12.03 \\
14.00 & 37.70 & 41.23 & 47.96 & 49.73 & 34.43 & 0.18 & 858.00 & 0.1210 & 11.75 \\
15.00 & 38.70 & 39.43 & 46.73 & 47.76 & 35.53 & 0.13 & 783.24 & 0.0872 & 9.28 \\
16.00 & 35.70 & 36.46 & 45.90 & 47.46 & 34.56 & 0.09 & 583.08 & 0.0604 & 8.64 \\
\hline
\end{tabular}

\subsection{Discussion}

The results and discussion can be displayed in graphical form so based on the tendency on the graph, a causal relationship will be seen and several conclusions can be drawn. The graph in question can be seen in Figures 3 and 4 and Figure 5 below.

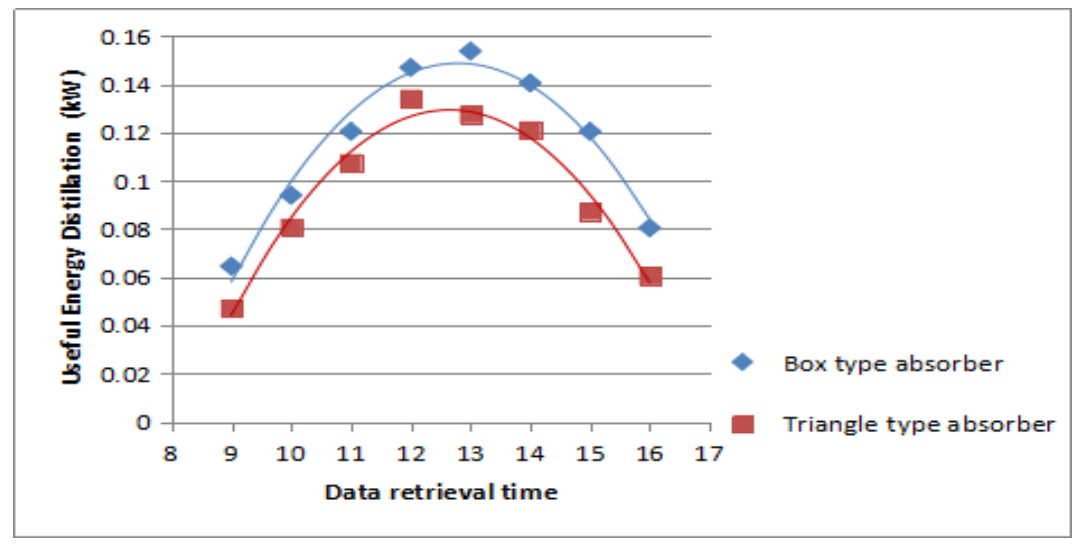

Figure 3. The Relationship Between Time and Distillation Useful Energy.

Based on the graph above shows that the time of data collection is very influential on the useful energy of distillation generated by the distillator either using a box type absorber or a triangle type absorbent. This happens because the afternoon the intensity of sunlight will also be higher, except in cloudy conditions. So that the heat energy produced by the destilator is also getting bigger over time. In addition, the useful energy of distillation is greatly influenced by the mass value of the distilled water $(\mathrm{kg})$, the latent heat of evaporation $(\mathrm{kJ} / \mathrm{kg})$ and the time (s) needed to produce distilled water. Other factors that influence the useful energy of the distillation are the design of the device itself and the high level of water in the basin.

Because if the water level in the basin is not taken into account, the water will take too long to heat and produce water vapor, thus inhibiting the process of brackish water distillation into fresh water due to poor tool design. It can also be seen from the graph that the distillation useful energy increases parabolically, where at 12,13 and 14 WITA both of these heat absorber designs produce the highest useful energy, this happens because the highest light intensity occurs at 12 to 14 WITA. Furthermore, at 15 to 16 WITA it was seen that the useful energy decreased slowly as the intensity of solar radiation decreased. The highest useful distillation energy in the box 
type solar radiation absorber design is $0.1537 \mathrm{~kW}$ at 13 WITA. While the highest useful distillation energy in the triangle type absorbent design that is equal to 0.1341 at 12 WITA.

From the graph above it can also be seen that the design of the destilator using a box type absorber can produce greater useful energy when compared to the design of a destilator that uses a triangle type absorber. This happens because the box type has greater area and surface radiation absorption, so that it can absorb more heat and can accelerate the process of heating water in the destilator basin and produce more mass $(\mathrm{kg})$ of distilled water when compared to the triangle type design. From the graph, it can be seen that the box type absorber design produces average distillation useful energy which is $0.115 \mathrm{~kW}$, whereas in the triangle type design the distillation useful energy can produce an average energy that is equal to $0.095 \mathrm{~kW}$.

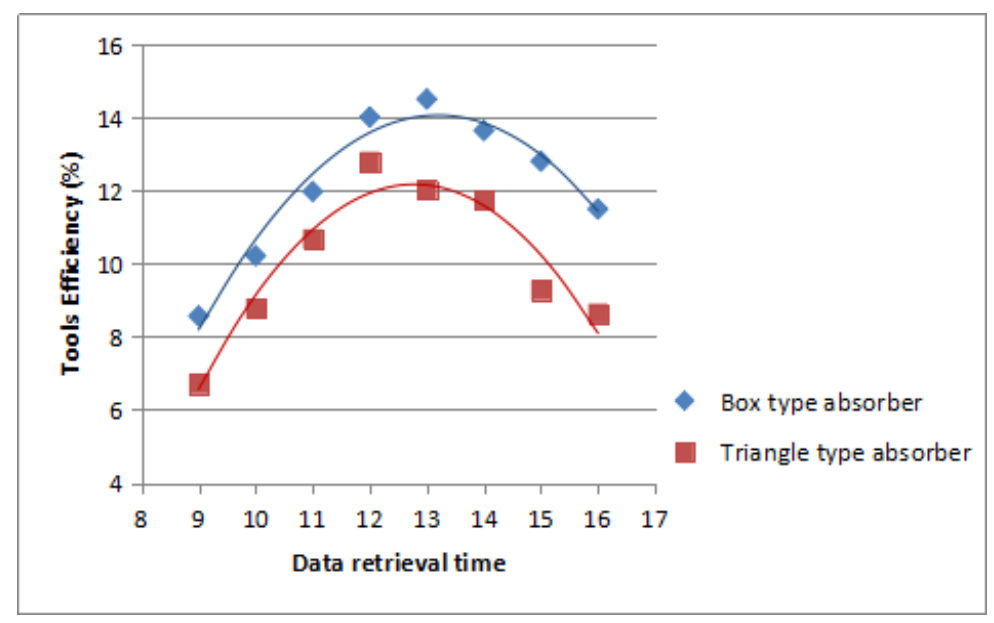

Figure 4. Relationship Between Time and Distillation Equipment Efficiency.

Based on the graph above it can be seen that the time of data retrieval is very influential on the efficiency of the distillation tool produced by the distillator. This happens because the distillation efficiency is greatly influenced by the mass value of the distilled water $(\mathrm{kg})$, the latent heat of evaporation $(\mathrm{kJ} / \mathrm{kg})$, the cross-sectional area of the glass $(\mathrm{m} 2)$, the intensity of solar radiation $(\mathrm{W} / \mathrm{m} 2)$, and the time required for produce distilled water $(\mathrm{s})$. It can also be seen from the graph that the efficiency of the distillation device increases parabolically, where at 12,13 and 14 WITA both of these heat absorber designs produce the highest efficiency, this is because the highest light intensity occurs at 12 to 14 WITA. But then at 15 and 16 WITA it was seen that the efficiency of the distillation equipment continued to decrease slowly as the intensity of solar radiation decreased. This happens because the useful energy received by the destilator also tends to decrease along with decreasing the intensity of sunlight. The highest efficiency of distillation equipment occurs in the design of a box type solar radiation absorber that is equal to $14.51 \%$ at 13 WITA. While the efficiency of the highest distillation apparatus in the triangle type absorbent design that is equal to $12.80 \%$ at 12 WITA.

In addition, it is also seen that the design of the distillator by using a box type absorber can produce greater distillation tool efficiency when compared to the triangle type radiation absorber design. This happens because the box type generates useful distillation energy and a greater area of the surface absorbent of radiation, so that it can evaporate brackish water into clean fresh water products during the distillation process. Thus, it can produce a mass of fresh water $(\mathrm{kg})$ 
more distillation results when compared to the design of the triangle type. In the box type radiation absorber design the efficiency of the resulting distillation device is an average of $12.1575 \%$ while in the design of a triangle type constellation absorber the efficiency of the resulting distillation tool is an average of $10,083 \%$.

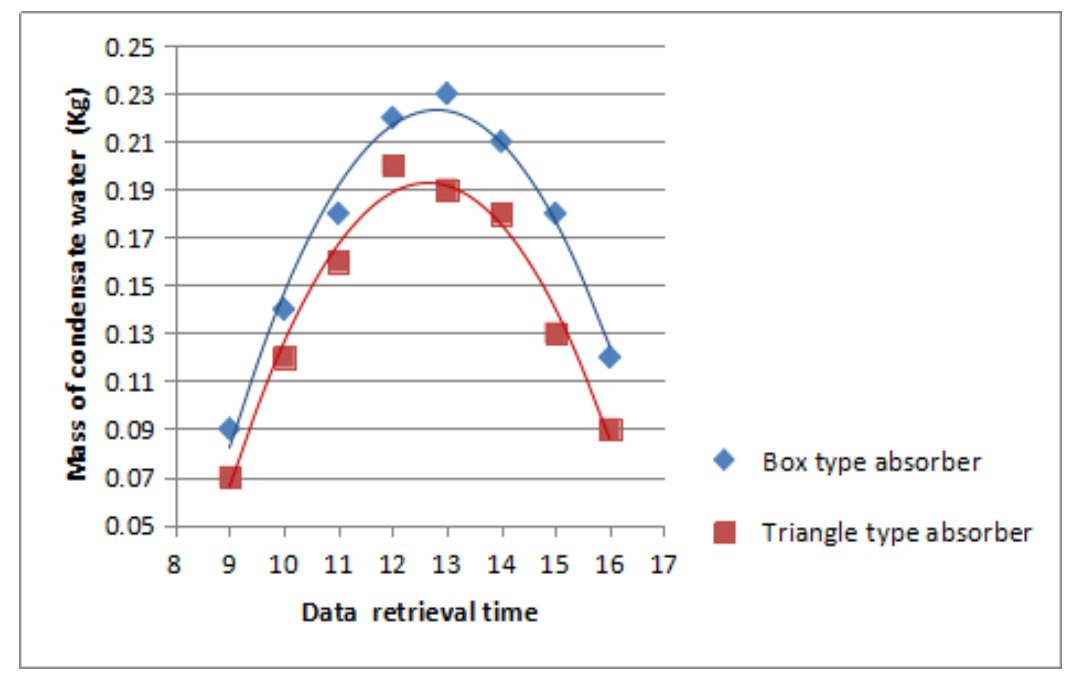

Figure 5. Relationship Between Time and Condensate Water Mass.

Based on the graph above, the timing of data collection is very influential on the mass of condensate water produced by a solar destilator design using either a box type absorber or a triangle type absorber. This happens because the intensity of solar radiation received by the distillator is very influential on the mass of condensate water, the greater the intensity of solar radiation, the greater the heat received by the absorbent plate and heats brackish water in the distillator, thus producing water vapor that is no longer salty or freshwater.

Based on the graph also shows that the mass of condensate water increases parabolically over time, so that at 14:00 to 16:00 WITA has a tendency to decrease. This happens because the intensity of solar radiation has decreased with the sun's inclination towards the west, so that the automatic heat received by the destilator gets smaller. In addition, the mass of condensate water is also strongly influenced by the design of a solar radiation absorbent plate, where in the graph the box absorber produces the highest condensate water mass of $0.23 \mathrm{~kg}$ at 13.00 WITA, while the triangle type absorbent produces the highest condensate water mass of $0.20 \mathrm{~kg}$ at 12.00 WITA. So that when averaged, the box type solar absorbent produces 1.37 liters per day, while the triangle type absorber produces 1.14 liters per day.

\section{Conclusion}

From the results of the discussion that has been carried out, it can be concluded that:

1. In brackish water distillator design using box type solar radiation absorption, it can produce a maximum tool efficiency of $14.51 \%$, at 13.00 WITA.

2. In brackish water distillator design using triangle type solar radiation absorption, it can produce a maximum tool efficiency of $12.80 \%$ at 12.00 WITA. 
3. When averaged, the box type solar absorbent produces 1.37 liters per day, while the triangle type absorber produces 1.14 liters per day.

\section{References}

[1] Walangare, K.B.A; Lumenta, A.S.M; Wuwung, J.O; Sugiarso, B.A. 2013. Rancang Bangun Alat Konversi Air Laut Menjadi Air Minum Dengan Proses Destilasi Sederhana Menggunakan Pemanas Elektrik. e-Jurnal

[2] Tanusekar H; Sutanhaji A.T 2014. Rancang Bangun dan Uji Kinerja Alat Desalinasi System Penyulingan Menggunakan Panas Matahari Dengan Pengaturan Tekanan Udara. Jurnal Keteknikan Pertanian Tropis dan Biosistem. Vol. 2 No. 1, Februari 2014, 1-8.

[3] Nurhayati I ; Purwoto S. 2014. Pengolahan Air Payau Berbasis Kimia Melalui Tekno Membran Reverse Osmosis (RO) Terpadukan DenganKkoagulan dan Penukar Ion. Prosiding Seminar Nasional Kimia, ISBN : 978-602-0951-00-3. Jurusan Kimia FMIPA Universitas Negeri Surabaya, 20 September 2014.

[4] Handayani N; Nugroho. F. T; Fitri. P.S. 2014. Analisa Kinerja Termal Solar Apparatus Panel pada Alat Destilasi Air Payau dengan System Evaporasi Uap Tenaga Matahari Menggunakan CFD. JURNAL TEKNIK POMITS Vol. 2, No. 1, (2014) ISSN: 2337-3539 (2301-9271 Print)

[5] Tambunan. S. F; Edisar. M; Junaidi. M. 2015. Destilasi Air Laut Menggunakan Pemanas Matahari dengan Reflektor Cermin Cekung. Jurnal JOM FMIPA Volume 2 No. 1 Februari 2015.

[6] Lianda. J; Enda. D; Ariadi; Suhaimi; Wira. M. 2015. Pengolahan Air Laut Menggunakan Generator Uap Untuk Menghasilkan Air Tawar. Seminar Nasional Teknologi Informasi, Komunikasi dan Industri (SNTIKI). ISSN :2085-990. Pekanbaru, 11 November 2015.

[7]. Astawa. K; Sucipta. M; Negara. A. G. P.I. 2011. Analisa Performansi Destilasi Air Laut Tenaga Surya Menggunakan Penyerap Radiasi Surya Tipe Bergelombang Berbahan Dasar Beton. Jurnal Ilmiah Teknik Mesin Cakra M Vol. 5 No.1. April 2011 (7-13) 